\title{
$\phi_{\text {review }}$ \\ 1993 MRS Fall Meeting Boston, Massachusetts November 29-December 3
}

\author{
Meeting Chairs: \\ Philippe M. Fauchet, University of Rochester \\ David B. Poker, Oak Ridge National Laboratory \\ Alan I. Taub, Ford Research Laboratory
}

The 1993 MRS Fall Meeting brings with it the 20th anniversary of the first MRS Meeting, held in 1973. To celebrate, nearly half of the symposia will open with brief historical remarks. Then, researchers will build on that history, in 26 symposia- 10 of them new. The meeting, to be held at the Boston Marriott and Westin Hotel/Copley Place, will also incorporate short courses and tutorials, an exhibit of materials products and services, special presentations by award recipients and by new Department of Energy (DOE) Secretary Hazel O'Leary, a society-wide colloquium, an education workshop, plus panel discussions and special sessions tucked into the technical symposia.

\section{Special Events}

The "Society-Wide Colloquium" on Monday morning will address the use, misuse, and non-use of information by the materials research community. Speakers will consider such questions as: Why isn't literature read as diligently in the U.S. as in other countries? What are the weak links in the information chain? What information tools are available? And, what can MRS do?

Monday evening, the plenary talk will be presented by DOE Secretary O'Leary.

A workshop Tuesday morning on the National Science Foundation undergraduate materials education initiative will review the progress of innovative materials curricula covering materials synthesis and processing. The last segment of the session will be an interactive panel discussion.

Wednesday evening is the awards cere- mony. Awards presented this year include the Graduate Student Awards, the Von Hippel Award, the MRS Medal Award, and the Turnbull Lectureship. A presentation by the Von Hippel Award recipient will follow the awards ceremony.

Symposium $X$, a noon session consisting of authoritative reviews for nonspecialists, will cover fullerenes and carbon materials, lithium microbatteries, molecular electronics, rotary engines in biology, polymers for pharmaceutical applications, and photonic materials.

\section{Technical Symposia}

Individual technical sessions are listed in the matrix on the following pages. In addition to oral presentations Monday through Friday, poster sessions will be held Monday through Thursday evenings. Over 3,000 oral and poster presentations are planned.

To address the increasing pressure of performing research with commercial relevance, Symposia I-Developing Materials Processes for Factories-will cover measures of performance and the processing of metals, plastics, ceramics, and semiconductors. The symposium will consist of all invited speakers, leading off with John Hopps, director of the Materials Research Division of the National Science Foundation.

The "Balluffi Fest," a three-day series of invited talks, will celebrate the approaching 70th birthday of Robert $W$. Balluffi through presentations on point defects, grain boundaries, and interfaces, and will include highlights of Balluffi's life and accomplishments.

Biomaterials are addressed in two new symposia, one covering drug and cell delivery and the other looking at biomaterials by design-for example, for making molecular motors or genetically engineered pores that function as metal ion biosensors.

A cluster of symposia on electronic materials includes new symposia on diagnostic techniques for processing, and on the physics and application of defects in advanced semiconductors.

Other new symposia include materials for advanced solid-state lasers; silicides, germanides and their interfaces; determining nanoscale physical properties of materials by microscopy and spectroscopy; gas-phase and surface chemistry in electronic materials processing; and metal-organic chemical vapor deposition of electronic ceramics.

In a Thursday evening session of Symposium $\mathrm{Ca}$, Interface Control of Electrical, Chemical, and Mechanical Properties, T. Ohmi (Tohoku University) will give a Japanese view of materials issues in semiconductor technology, and T. Seidel (SEMATECH) will describe SEMATECH's road map.

An interesting twist to Symposium V, Scientific Basis for Nuclear Waste Management, is a session and panel discussion on objectives and limitations of scientific studies. This session on Tuesday morning will present a picture of the problems associated with establishing the safety of current approaches to nuclear waste management.

A panel discussion on Wednesday morning in Symposium A, Materials Synthesis and Processing Using Ion Beams, will address the road map for ion processing, examining electronic and automotive applications and new processes and materials.

Other ongoing symposia encompass superconductivity-including a session on the new mercury cuprates-fullerenes, thin-film evolution, defect-interface interactions, high-temperature silicides and refractory alloys, amorphous materials, covalent ceramics, complex fluids, disordered materials, and organic solid-state materials.

For further details about the meeting, see the 1993 MRS Fall Meeting Program, which has been mailed to all MRS members. If you need a program or would like to register, call the MRS Meetings Department at (412) 367-3003; fax (412) $367-4373$

\section{MRS FALL MEETING} SYMPOSIUM I: DEVELOPING MATERIALS PROCESSES FOR FACTORIES

To address the increasing pressure of performing research with commercial relevance, Symposium I, consisting of all invited speakers, will address how to develop materials processes for factories, including processing of metals, plastics, ceramics, and semiconductors. 